\title{
Underlying correlates of consumers' attitudes towards Chinese apparel and relationship with purchase intention in South Africa
}

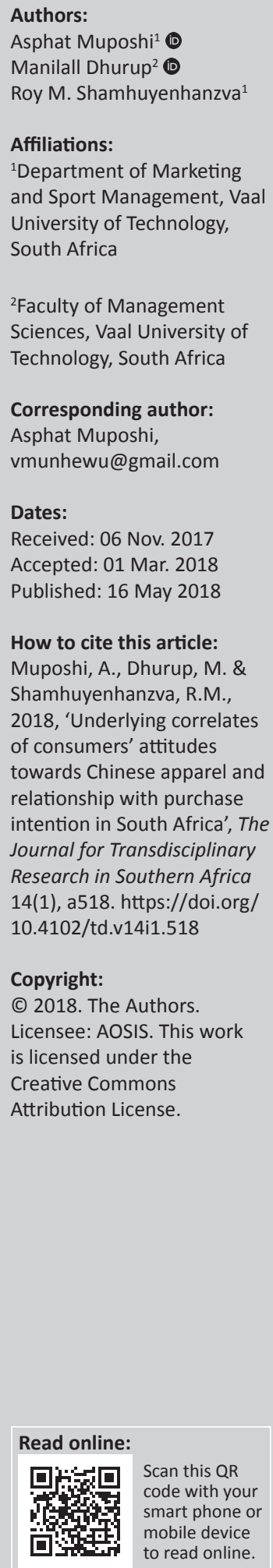

\begin{abstract}
The study examined the influence of South African consumers' attitudes and purchase intention towards Chinese apparel. A survey of South African consumers who had purchase experience of Chinese apparel was conducted to test the hypothesised relationships. Structural equation modelling results indicated that economic animosity and consumer ethnocentrism are negatively related to attitudes towards Chinese apparel and consumer purchase intention. The study revealed a significant, positive relationship between cosmopolitanism, attitudes towards Chinese apparel and consumer purchase intention. In addition, the findings of the study suggest the importance of cosmopolitanism, consumer ethnocentrism and animosity in market segmentation, targeting, positioning and market potential analysis. The study provides managerial implications for the marketing of Chinese apparel in South Africa.
\end{abstract}

\section{Introduction}

Consumer buying behaviour in domestic and global markets is principally driven by rational and emotional factors (Schnettler et al. 2011; Wang, He \& Li 2013). Drawing from the concept of neuromarketing, marketers utilise rational and emotional cues to design marketing strategies (Plassmann, Ramsoy \& Milosavljvevic 2012). Rational reasoning, which is underpinned by the utility theory, holds that global products offer consumer-centric benefits such as variety, novelty, quality and prestige that drive purchase intentions (Lew \& Sulaiman 2014; Riefler 2012). In contrast, emotional reasoning advances that emotions and normative sentiments play a pivotal role in the purchase of foreign products (Dmitrovic, Vida \& Reardon 2009). Whilst a standardisation strategy is used to enhance the utilitarian benefits of products earmarked for foreign markets, incorporating the emotional component in the global marketing mix remains a challenge for marketers (Wang et al. 2013). Part of the challenge emanates from mixed empirical evidence on salient emotional factors that influence consumers when buying foreign products (Cleveland et al. 2011; Nes, Yelkur \& Sikoset 2012; Wang et al. 2014). Given this background, the objective of this study is to understand consumer attitudes towards Chinese apparel and relationship with purchase intention in South Africa.

\section{Contextual setting of the study}

The selection of South Africa as a contextual setting for the study and Chinese apparel as a unit of analysis was informed by a number of factors. With an estimated population of 54 million, South Africa is one of Africa's economic hubs, representing a significant market for both domestic and foreign products (Besada, Tok \& Winters 2013; Wasserman 2012). Of greater importance to global marketers is that South African consumers are increasingly becoming more ambivalent towards foreign products owing to the growth in nationalism. For example, Pentz, Terblanche and Boshoff (2014) note that feelings of ethnocentrism have become pervasive in contemporary South Africa, with implications on the purchase of foreign-made products. The growth in nationalism is partly attributed to the proudly South African campaign that encourages South Africans to buy homemade products (Bevan-Dye, Garnett \& De Klerk 2012). Chinese apparel was selected as the locus of economic animosity (EA) of South African consumers for the following reasons. Firstly, China is the largest trading partner of South Africa and the relationship between the two countries oscillates between scepticism and controversy (Rebol 2010; Wasserman 2012; Zeleza 2008). Secondly, China's economic inroads into South Africa have generated much debate. For example, International trade analysts (e.g. Lamprecht 2014; Wasserman 2012) perceive that South Africa is 'settling for crumbs' in what appears to be an imbalanced trade relationship. Thirdly, as China continues to deepen its trade with South Africa under the auspices of BRICS (Wasserman 2012), 
it is important to understand South African consumers' attitudes towards Chinese apparel.

\section{Problem statement}

The dominant perception that prevails among South Africans is that the continued influx of cheap imports from China is deindustrialising South Africa's textile industry (Edwards \& Jenkins 2013). The Confederation of South African Trade Unions (COSATU) characterises a glut of cheap products from China as a 'tsunami' that has the potential of damaging local companies (Wasserman 2012). In addition, Chinese apparel have been criticised for being counterfeit with the 'Fong Kong' tag affixed to products made in China (Alden \& Wu 2014). A study conducted by Rebol (2010) showed that only $44 \%$ of the surveyed population in South Africa expressed positive views about Chinese products. The South African textile industry blames cheap Chinese apparel for eroding profit margins with ripple effects on employment and economic growth (Morris \& Einhorn 2008).

Despite the growth in academic interest in South Africa and China trade relations, research on consumer attitudes towards Chinese products remains low. To date, the majority of studies have mainly focused on South Africa and China's trade relationship (e.g. Obiorah 2007; Rebol 2010; Wasserman 2012; Zeleza 2008). Relatively few studies have been directed towards understanding consumer attitudes towards Chinese apparel. A notable study by Pentz et al. (2014) only focused on consumer ethnocentrism and did not consider other important attitudinal factors such as animosity and cosmopolitanism. This study attempts to close this gap by examining South African consumers' attitudes and purchase intentions towards Chinese apparel. In addition, this study examines the relationship between attitudes towards Chinese apparel and consumer purchase intentions (CPIs). The Chinese apparel was considered as the ideal product category because China is one of South Africa's biggest trading partners in this product category.

\section{Literature review and hypotheses development \\ Consumer attitudes towards foreign products}

Today's globalised marketplace is inundated with a wide assortment of products of diverse national origins (Nijssen \& Douglas 2004; Pentz et al. 2014). Within this cluttered marketplace, consumer purchase decisions are increasingly informed by consumers' nationalist sentiments (Cleveland, Laroche \& Papadopoulos 2009). To survive the cut-throat competition characterising contemporary markets, it is imperative for marketers to understand consumers' attitudes towards foreign-made products (Dimofte, Johansson \& Bagozzi 2010; Riefler 2012). In consumer behaviour, attitudes are construed as 'a summary evaluation of a psychological object captured in such attribute dimensions as good-bad, harmful-beneficial, pleasant-unpleasant, and likeabledislikeable' (Ajzen 2001:29).
According to Liu et al. (2006), product quality, country of origin and unavailability of domestic product alternatives influence attitudes towards foreign products. Apart from product-related sentiments, feelings of ethnocentrism and hostility towards foreign products also influence CPIs (Shimp \& Sharma 1987). For this reason, Akdogan et al. (2012) identified 'economic animosity', 'consumer ethnocentrism' and 'cosmopolitanism' as the main attitudinal factors that influence the purchase of foreignmade products. These factors are discussed in the following sections.

\section{Consumer ethnocentrism}

The concept of ethnocentrism has ancient roots. The pioneering work of Sumner (1906) described ethnocentrism as the enduring belief that an individual's social orientation is superior to others and ought to be considered as a benchmark for behavioural performance. When applied to nationhood, the overriding perception in individuals with a high ethnocentric orientation is that the country of birth is superior relative to others (Parker, Haytko \& Hermans 2011). From a marketing perspective, a company is considered ethnocentric when it perceives that products that succeed in its home market will automatically succeed in global markets (Keegan \& Green 2008). Accordingly, Purwanto (2014) defines ethnocentrism as a castellation of feelings of nationalism, morality and patriotism.

The term consumer ethnocentrism was derived from the general principle of ethnocentrism and captures the inherent beliefs of consumers towards foreign-made products (Bandyopadhyay 2014). Consumer ethnocentrism emanates from a socialisation process that acts as a baseline for evaluating products from foreign markets (Ahmed et al. 2013). Ethnocentric perceptions play a pivotal role if consumers are of the view that the purchase of foreign products threatens personal livelihoods and the country's well-being (Klein, Ettenson \& Morris 1998). Consumers who are highly ethnocentric perceive that the purchase of foreign-made products is detrimental to the domestic economy and hence their loyalty resides in home-made products (Jimenez \& Martin 2010). To highly ethnocentric consumers, the purchase of home-made products amounts to promoting their own cultural identity (Cleveland et al. 2009). In consumption settings, consumers with high levels of ethnocentrism are driven by the normative belief that the consumption of domestic products is beneficial to the economy and society (Ahmed et al. 2013). Moreover, highly ethnocentric consumers regard home-made products as of more superior quality than foreign-made products (Bandyopadhyay 2014). Conversely, consumers with low levels of ethnocentrism evaluate products based on their value proposition rather than origin (Jimenez \& Martin 2010; Schnettler et al. 2011). Based on the foregoing discussion, it is hypothesised that:

H1: There is a significant negative relationship between consumer ethnocentrism and attitude towards Chinese apparel among South African consumers. 


\section{Economic animosity}

Apart from ethnocentric perceptions directed to foreign products, the feelings of hostility directed towards the country of origin of imported products have the potential of inducing consumer apathy (Fong, Lee \& Du 2014). In international marketing literature, the term animosity was coined by Klein et al. (1998) to denote the enduring feelings of hatred directed to a certain country. According to De Nisco et al. (2016), such feelings of hatred may emanate from historical conflicts (war animosity) or accusations of unfair trade practices (EA). In international marketing literature, consumer animosity is defined as the resentment of consumers towards the geographical origin of the product (Amine 2008; Jimenez \& Martin 2010). According to Riefler and Diamantopoulos (2007), consumer animosity is a macromarketing concept that portrays the value attached by consumers to the virtues of societal norms and altruism in purchase decisions.

Consumers who exhibit significant levels of animosity towards a particular country tend to be less likely to purchase products manufactured in that country (Hoffmann, Mai \& Smirnova 2010). To cite an example, a study conducted by Bahaeeand Pisani (2009) showed that animosity of Iranian consumers towards United States resulted in negative purchase intentions although the products were considered a necessity. In particular, high levels of animosity have the potential of devaluing the quality of foreign products, inducing consumer apathy and nurturing the tendency of boycotting products from the hostile country (Hoffmann et al. 2010). Based on the foregoing discussion it is hypothesised:

H2: Economic animosity is negatively related to attitude towards Chinese apparel among consumers in South Africa.

\section{Cosmopolitanism}

The market penetration of foreign products also depends on the level of cosmopolitanism in the domestic market (Riefler, Diamantopoulos \& Siguaw 2012). The pioneering work of Merton (1957) defined cosmopolitanism as behavioural actions that are not constrained by cultural orientations. Since then, the concept of cosmopolitanism has evolved to encompass cultural openness and tolerance, acculturation, world-mindedness and internationalism (Kurasawa 2004; Parts \& Vida 2011; Skrbis, Kendall \& Woodward 2004). Accordingly, Cannon and Yaprak (2002) defined cosmopolitanism as an individual's commitment to embrace and learn other cultures. The values of cosmopolitans are shaped by the quest for a global identity, versatility and are less inclined to conform to a particular culture (Yegenoglu 2005).

From a marketing perspective, consumers with a cosmopolitan orientation are more receptive to foreign consumption values and products of foreign origin (Gao, Andras \& Huang 2013). For cosmopolitans, the desire for a global consumption identity outweighs the feelings of ethnocentrism and animosity (Schroeder 2009).
Cosmopolitanism is spurred by the growth in globalisation that accords consumers an opportunity to learn other cultures, which ranslates into favourable perceptions towards foreign products (Riefler \& Diamontopoulos 2009). In consumer buyer behaviour, cosmopolitanism distinguishes consumer segments that are favourable to foreign-made products from those favouring local products (Steenkamp \& De Jong 2010). A study conducted by Strizhakova, Coulter and Price (2012) showed that the level of cosmopolitanism among consumers varies with the level of economic development and cultural setting of the target market. Thus, an insight into the level of cosmopolitanism in an emerging economy with diverse cultures such as South Africa (Pentz et al. 2014) is deemed necessary. Hence, this study hypothesised that:

H3: Consumer cosmopolitanism positively influences attitude towards Chinese apparel among consumers in South Africa.

\section{Attitudes and intention relationship}

The theory of reasoned action (TRA) has been widely employed to explain the influence of attitude on behavioural intention (Bian \& Forsythe 2012; Jin \& Kang 2011; Malhotra \& McCort 2001). The TRA posits that an individual's behaviour is influenced by intention, which is a function of two constructs: attitude towards the behaviour and subjective norm (Ajzen 2001). According to Fishbein and Ajzen (1975), intention is defined as the determination to act in a certain manner. Attitude towards behaviour refers to the individual's assessments of whether to execute a certain behaviour or not (Kim \& Cheong 2011). A stronger intent to engage in a certain behaviour is normally accompanied by the desire to perform such behaviour (Kim \& Cheong 2011). Given the influence of attitudes on CPI, the study hypothesised that:

H4: There is a positive relationship between attitude towards Chinese products and purchase intentions among South African consumers.

Based on the theoretical perspectives discussed and the research gaps identified, the proposed research model and the posited hypotheses are shown in Figure 1.

\section{Competing models}

Apart from the posited relationships depicted in research model 1, direct and indirect relationships between the

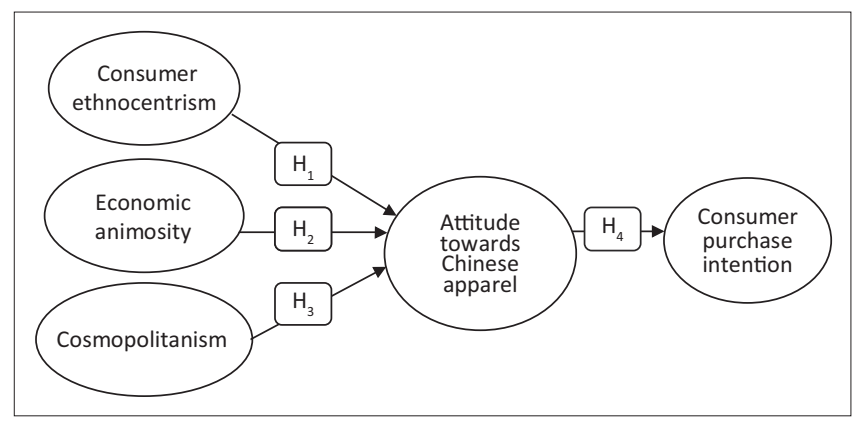

$\mathrm{H}$, hypothesis.

FIGURE 1: Research model 1. 


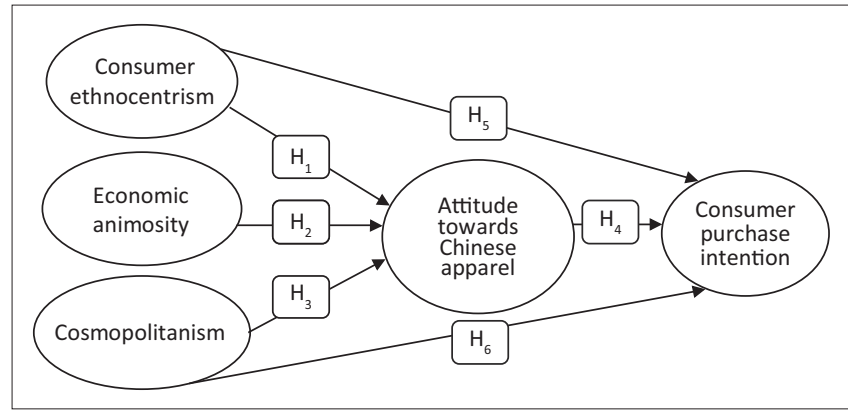

$H$, hypothesis.

FIGURE 2: Alternative research model 2.

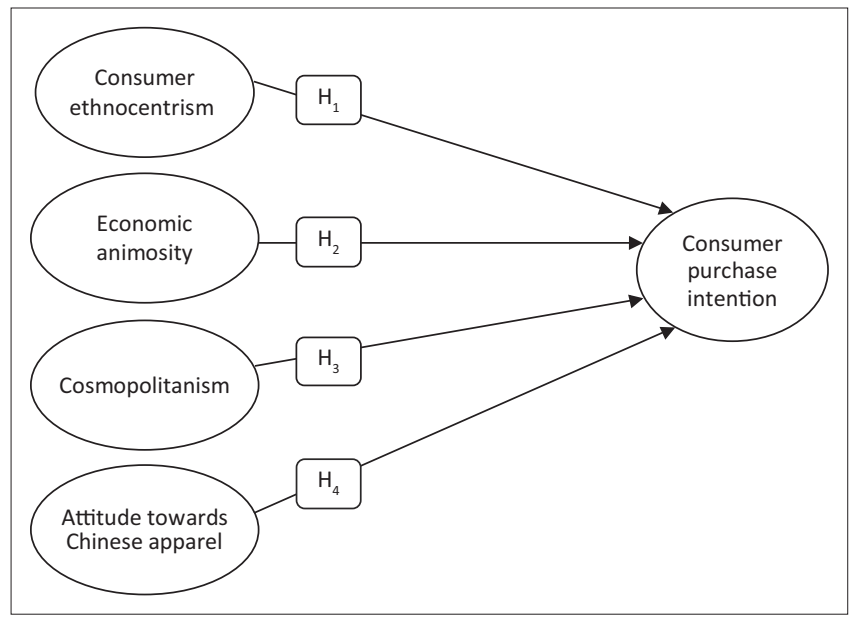

$\mathrm{H}$, hypothesis.

FIGURE 3: Alternative Model 3.

variables under investigation are plausible. Drawing from a study conducted by Parker et al. (2011) that showed a positive relationship between consumer ethnocentrism and willingness to buy foreign products, the possibility of a direct relationship between consumer ethnocentrism and $\mathrm{CPI}$ is also examined. In addition, based on the study by Gao et al. (2013), consumers with a cosmopolitan orientation have favourable intentions to buy foreign products. Hence, it is plausible that a direct relationship exists between cosmopolitanism and CPI. Based on the foregoing discussion, it is posited that:

H5: Consumer ethnocentrism positively influences consumer purchase intentions among consumers in South Africa.

H6: Cosmopolitanism positively influences consumer purchase intentions among consumers in South Africa.

The alternative research model 2 that incorporates the additional paths is shown in Figure 2.

In international marketing, consumer ethnocentrism, EA and cosmopolitanism are also posited as direct antecedents of CPI (Fong et al. 2014; Klein et al. 1998). In addition to the normative and affective attitudinal components integrated in the ethnocentrism and animosity variables (Nes et al. 2012; Smith \& Qianpin 2010), the cognitive attitudinal component also influences purchase intention towards foreign products (Roth \& Diamantopoulos 2009). To validate this theoretical argument, this study further tests the direct effects of consumer ethnocentrism, animosity, cosmopolitanism and attitude on CPI, as shown in Figure 3.

\section{Research methodology}

The study employed a quantitative approach to verify the hypothesised relationships in South Africa's import-oriented apparel retail sector. A structured, self-administered questionnaire through a mall-intercept method was utilised. The following steps were followed in the research design:

\section{Target population and sampling frame}

The target population for the study was South African consumers who have purchase experience of Chinese apparel. The respondents were drawn from the major shopping malls which sell Chinese apparel in the Gauteng Province. The Gauteng Province was considered the ideal setting for the study owing to its status as the economic hub of South Africa and also because it is an emblem of cultural diversity in South Africa. In the absence of the sample frame, the identified shopping malls (survey location) were used as the sampling frame.

\section{Sampling method and sample size}

To examine South African consumers' attitudes towards Chinese apparel products, data were collected between March and April 2015 through the use of convenience sampling employing a mall-intercept technique. Using this technique, shoppers were approached and requested to complete a structured self-administered questionnaire. A total of seven major shopping malls that sell Chinese apparel was selected. In total, 500 questionnaires were administered and after accounting for incomplete responses to some parts of the questionnaire, 410 questionnaires were considered valid for analysis. This resulted in a data set adequate for execution of multivariate statistics such as confirmatory factor analysis (CFA) and structural equation modelling (SEM) (Pallant 2011).

\section{Research instrument}

The questionnaire consisted of four sections. Section A solicited demographic information of respondents. Section B solicited information on attitudes towards foreign-made products that included consumer ethnocentrism, EA and cosmopolitanism constructs. The questions in Section B were adapted from validated instruments employed in previous studies conducted by Klein et al. (1998) and Cleveland et al. (2011). Section C covered attitudes towards foreign products, measured using a four-item semantic differential scale developed by Shimp and Sharma (1987). Section D sought information on CPI using a five-item scale adapted from Klein et al. (1998). All items in Sections B and C were measured on a five-point Likert-type scale denoted by strongly agree (5) and strongly disagree (1). The questionnaire was pilottested to assess content validity and appropriateness of questions with 50 respondents drawn from one shopping mall. The respondents who participated in the pilot study 
were not part of the main study. The pilot-tested questionnaire returned acceptable Cronbach's alpha values, ranging from 0.704 to 0.899 , that were above the minimum threshold value of 0.70 (Pallant 2011). In line with ethical practices in research, each questionnaire was accompanied by a covering letter explaining the purpose of the study (Gupta 2011). To enhance anonymity, no names were attached to the returned questionnaires (Polit, Beck \& Hungler 2001).

\section{Data analysis}

The Statistical Package for Social Sciences (SPSS) 23.0 and Analysis of Moment Structures (AMOS) 23.0 were used for data analysis. The statistical approaches utilised in this study include descriptive statistics, exploratory factor analysis, CFA, correlational analysis and SEM.

\section{Sample composition}

The majority of the respondents were women $(61 \%, n=250)$, with the remainder $(39 \%, n=160)$ being men. In terms of age, the majority of the respondents, $87.6 \%(n=359)$ were aged between 18 and 40 years, with $12.4 \%(n=51)$ constituted by respondents over 50 years. With regard to education, an estimated $42 \%(n=172)$ held a matriculation certificate, whilst $38 \%(n=155)$ were in possession of a diploma. Furthermore, approximately $18 \%(n=74)$ were in possession of a degree and almost $2 \%(n=8)$ had attained a postgraduate qualification. In terms of monthly income, almost 95\% $(n=390)$ earned below R15 000.00, whilst approximately 5\% $(n=20)$ were earning above R15 000.00.

\section{Reliability and validity of measured items}

The internal consistency of the measurement items was assessed using Cronbach's alpha coefficient, the item-tototal values and composite reliability. Internal consistency measures the degree of interrelatedness of measurement items that are designed to measure the same construct (Hair et al. 2009). Composite reliability measures the degree to which observable variables measure the latent variable (Malhotra 2009). It provides a robust measure of reliability by taking into account the contribution of each latent factor to each item and each item's error (Hair et al. 2009). The Cronbach's alpha and composite reliability values for all scales as reported in Table 1 are above the recommended benchmark levels of 0.70 (Zikmund \& Babin 2010). Furthermore, item-to-total correlations ranged from 0.560 to 0.834 , which is above acceptable threshold of 0.5 (Anderson \& Gerbing 1988). In order to assess the content validity of the questionnaire, a pre-test was conducted as recommended by Malhotra (2009). One big shopping mall located in Johannesburg, which was not participating in the main study, was used for the pre-test. Based on the results of the pre-test, minor adjustments were made to the questionnaire. The study employed the measure of average variance extracted (AVE) to assess discriminant validity was evident (Fornell \& Larcker 1981). The AVE measures the amount of variance captured by the construct and its items relative to the amount of variance owing to measurement error (Bagozzi \& Yi 2012). According to Fornell and Larcher (1981), discriminant validity is evidenced when the square root of AVE is greater than the correlation between the construct and the construct in the model. Discriminant validity was evidenced as the AVEs of individual variables were greater than the squared correlations between the relevant variables (Tables 2 and 3). Convergent validity, which measures the extent of positive associations of the measurement item with other items measuring the same construct, was assessed by inspecting the factor loadings (Malhotra 2009). As shown in Table 2, all item loadings of all constructs were greater than the baseline value of 0.5 , indicating the attainment of

TABLE 1: Reliability and validity measures.

\begin{tabular}{|c|c|c|c|c|c|c|c|c|c|c|}
\hline \multirow[t]{2}{*}{ Research construct } & \multirow{2}{*}{$\begin{array}{c}\text { Research } \\
\text { construct } \\
\text { abbreviation }\end{array}$} & \multicolumn{2}{|c|}{ Descriptive statistics } & \multicolumn{2}{|c|}{ Cronbach's test } & \multirow{2}{*}{$\begin{array}{l}\text { Composite } \\
\text { reliability }\end{array}$} & \multirow{2}{*}{$\begin{array}{l}\text { Average } \\
\text { variance } \\
\text { extracted }\end{array}$} & \multirow{2}{*}{$\begin{array}{c}\text { Average } \\
\text { square root }\end{array}$} & \multirow{2}{*}{$\begin{array}{c}\text { Shared } \\
\text { variance }\end{array}$} & \multirow{2}{*}{$\begin{array}{l}\text { Factor } \\
\text { loadings }\end{array}$} \\
\hline & & Mean & SD & Item-total & $\alpha$ value & & & & & \\
\hline \multirow{6}{*}{$\begin{array}{l}\text { Consumer } \\
\text { ethnocentrism (CE) }\end{array}$} & CE1 & \multirow{6}{*}{3.83} & \multirow{6}{*}{0.540} & 0.604 & \multirow{6}{*}{0.847} & \multirow{6}{*}{0.850} & \multirow{6}{*}{0.50} & \multirow{6}{*}{0.693} & \multirow{6}{*}{0.048} & 0.673 \\
\hline & CE2 & & & 0.630 & & & & & & 0.685 \\
\hline & CE3 & & & 0.641 & & & & & & 0.704 \\
\hline & CE4 & & & 0.614 & & & & & & 0.672 \\
\hline & CE5 & & & 0.657 & & & & & & 0.729 \\
\hline & CE6 & & & 0.631 & & & & & & 0.678 \\
\hline \multirow{3}{*}{$\begin{array}{l}\text { Economic } \\
\text { animosity (EA) }\end{array}$} & EA1 & \multirow{3}{*}{3.81} & \multirow{3}{*}{0.722} & 0.834 & \multirow{3}{*}{0.876} & \multirow{3}{*}{0.880} & \multirow{3}{*}{0.720} & \multirow{3}{*}{0.849} & \multirow{3}{*}{0.183} & 0.936 \\
\hline & EA2 & & & 0.816 & & & & & & 0.918 \\
\hline & EA3 & & & 0.646 & & & & & & 0.668 \\
\hline \multirow[t]{3}{*}{ Cosmopolitanism (CO) } & $\mathrm{CO} 1$ & \multirow{3}{*}{3.45} & \multirow{3}{*}{0.501} & 0.633 & \multirow{3}{*}{0.783} & \multirow{3}{*}{0.790} & \multirow{3}{*}{0.55} & \multirow{3}{*}{0.742} & \multirow{3}{*}{0.012} & 0.759 \\
\hline & $\mathrm{CO} 2$ & & & 0.602 & & & & & & 0.694 \\
\hline & $\mathrm{CO} 3$ & & & 0.639 & & & & & & 0.769 \\
\hline Attitudes towards & ATT1 & 352 & 050 & 0.652 & 0789 & م 790 & 065 & 0806 & 0086 & 0.865 \\
\hline & ATT2 & 3.52 & 0.550 & 0.652 & 0.189 & 0.190 & 0.03 & 0.000 & 0.000 & 0.748 \\
\hline Consumer & $\mathrm{C} 1$ & & & 0.645 & & & & & & 0.731 \\
\hline $\begin{array}{l}\text { purchase } \\
\text { intention (CPI) }\end{array}$ & $\mathrm{C} 2$ & & & 0.673 & & & & & & 0.754 \\
\hline & $\mathrm{C} 3$ & 2.97 & 0.570 & 0.613 & 0.834 & 0.840 & 0.51 & 0.714 & 0.204 & 0.667 \\
\hline & $\mathrm{C} 4$ & & & 0.691 & & & & & & 0.800 \\
\hline & C5 & & & 0.560 & & & & & & 0.597 \\
\hline
\end{tabular}

$\mathrm{CE}$, consumer ethnocentrism; $\mathrm{EA}$, economic animosity; $\mathrm{CO}$, cosmopolitanism; $\mathrm{ATT}$, attitudes towards foreign products; $\mathrm{CPI}$, consumer purchase intention. 
TABLE 2: Correlations between constructs.

\begin{tabular}{lccccc}
\hline Constructs & CE & EA & CO & ATT & CPI \\
\hline CE & 1.000 & - & - & - & - \\
EA & $0.428 \ddagger$ & 1.000 & - & - & - \\
CO & 0.072 & 0.078 & 1.000 & - & - \\
ATT & $-0.220 \ddagger$ & $-0.294 \ddagger$ & $0.270 \ddagger$ & 1.000 & - \\
CPI & $-0.245 \ddagger$ & $-0.217 \ddagger$ & $0.111 \dagger$ & $0.452 \ddagger$ & 1.000 \\
\hline
\end{tabular}

$\mathrm{CE}$, consumer ethnocentrism; EA, economic animosity; CO, cosmopolitanism; ATT, attitude towards foreign products; $\mathrm{CPI}$, consumer purchase intention.

$\dagger$, Correlation is significant at the 0.05 level (two-tailed); $\$$, correlation is significant at the 0.01 level (two-tailed).

convergent validity (Bagozzi \& Yi 2012). Predictive validity was measured through SEM. Table 1 provides the reliability and validity measures.

\section{Correlation analysis}

The non-parametric Spearman's correlation analysis was utilised to examine the extent of relationship among the five constructs in the study. The benchmarks suggested by Field (2009): small ( $r=0.10$ to 0.29 ), medium ( $r=0.30$ to 0.49 ) and large ( $r=0.50$ to 1.0) were used to explain the relationship between variables. The correlation coefficients in this study ranged from -0.245 to 0.452 , indicating the absence of multicollinearity as variables under investigation were not highly correlated. Table 2 presents the correlation analysis results.

\section{Measurement model fit assessments}

The fitness of the measurement model was assessed by conducting CFA by means of maximum estimation likelihood method using AMOS version 23.0. The measurement model refers to the relationship between latent variables and manifest variables within a given study (Anderson \& Gerbing 1988). The CFA model for the study comprises all latent and manifest variables, that is, consumer ethnocentrism (five-item scale), EA (three-item scale), cosmopolitanism (three-item scale), attitudes towards foreign apparel (twoitem scale) and CPI (five-item scale).

The quality of the measurement model was assessed by checking the significance of the item loadings of all the constructs. All items scored factor loadings above the minimum acceptable threshold of 0.50 and as such no items were deleted. The CFA yielded satisfactory fit: chi-square value over degree of freedom $\left(\chi^{2} / \mathrm{df}\right)=2.469$, Goodness-of-Fit Index $(\mathrm{GFI})=0.921$, Root Mean Square Error of Approximation $($ RMSEA $)=0.060$, Comparative Fit Index $($ CFI $)=0.940$, Incremental Fit Index (IFI) $=0.941$ and Tucker-Lewis Index $(\mathrm{TLI})=0.927$. All reported indices are within the recommended thresholds according to the cut-off criteria suggested by Bagozzi and Yi (2012), indicating the robustness of the measurement model.

\section{Structural models assessments}

The fitness of the posited structural model (model 1) and the competing models (models 2 and 3) were assessed by means of AMOS version 23.0, employing the maximum likelihood estimation. The structural model captures the relationships
TABLE 3: Structural model comparison.

\begin{tabular}{lccccc}
\hline Model fit indices & Model 1 & $\begin{array}{c}\text { Model 2 } \\
\text { (direct/indirect } \\
\text { effects) }\end{array}$ & $\begin{array}{c}\text { Model 3 } \\
\text { (direct } \\
\text { effects) }\end{array}$ & $\begin{array}{c}\text { Acceptable } \\
\text { value }\end{array}$ \\
\hline $\begin{array}{l}\text { Absolute fit } \\
\text { indices }\end{array}$ & $\chi^{2} / \mathrm{df}$ & 2.262 & 3.263 & 3.772 & $<3.00$ \\
& $\mathrm{GFI}$ & 0.926 & 0.896 & 0.878 & $>0.90$ \\
& $\mathrm{AGFI}$ & 0.902 & 0.864 & 0.844 & $>0.80$ \\
& $\mathrm{RMSEA}$ & 0.056 & 0.074 & 0.082 & $<0.08$ \\
Incremental & $\mathrm{NFI}$ & 0.910 & 0.868 & 0.845 & $>0.90$ \\
fit indices & $\mathrm{TLI}$ & 0.937 & 0.887 & 0.862 & $>0.90$ \\
& $\mathrm{CFI}$ & 0.947 & 0.904 & 0.881 & $>0.90$ \\
& $\mathrm{IFI}$ & 0.948 & 0.905 & 0.881 & $>0.90$ \\
\hline
\end{tabular}

GFI, Goodness-of-Fit Index; AGFI, Adjusted Goodness-of-Fit-Index; RMSEA, Roo Mean Square Error of Approximation; NFI, Normed Fit Index; TLI, Tucker-Lewis Index; $\mathrm{CFI}$, Comparative Fit Index; IFI, Incremental Fit Index.

TABLE 4: Structural equation modelling hypotheses testing results.

\begin{tabular}{lcccc}
\hline Paths & $\begin{array}{c}\text { Path } \\
\text { coefficients }\end{array}$ & $\begin{array}{c}\text { Standardised } \\
\text { estimates }\end{array}$ & $\boldsymbol{t}$ & Hypotheses results \\
\hline CET $\rightarrow$ ATT & -0.289 & 0.072 & -4.005 & H1: Supported $p<0.001$ \\
EA $\rightarrow$ ATT & -0.211 & 0.063 & -3.373 & H2: Supported $p<0.001$ \\
CO $\rightarrow$ ATT & 0.484 & 0.082 & 5.884 & H3: Supported $p<0.001$ \\
ATT $\rightarrow$ CPI & 0.560 & 0.062 & 9.091 & H4: Supported $p<0.001$ \\
\hline
\end{tabular}

CET, consumer ethnocentrism; EA, economic animosity; CO, cosmopolitanism; ATT, attitude towards Chinese apparel; CPI, consumer purchase intention; $t$, values.

among the latent variables (Hair et al. 2009). To ascertain the fitness of the structural model, absolute fit indices $\left(\chi^{2} / \mathrm{df}\right.$, GFI, Adjusted Goodness-of-Fit-Index (AGFI) and RMSEA) and incremental fit indices Normed Fit Index (NFI), TLI and IFI were used. Model 1 reported fit indices that are within the recommended thresholds, as suggested by Bagozzi and Yi (2012), indicating the fitness of the model to the data. However, model 2 yielded values that are not consistent with the acceptable values $\left(\chi^{2} / \mathrm{df}=3.263, \mathrm{GFI}=0.896, \mathrm{NFI}=0.868\right.$, $\mathrm{TLI}=0.887$ ). With regards to model 3 , only the AGFI $=0.844$ met the recommended threshold. Based on results presented in Table 3, model 1 was accepted for hypotheses testing as it was the best-fit model. The results of structural model comparisons are summarised in Table 3.

\section{Results of hypothesis testing}

The study employed SEM to verify the posited hypotheses. Table 4 presents the hypothesis testing results. The first hypothesis $\left(\mathrm{H}_{1}\right)$ predicted a negative relationship between consumer ethnocentrism and attitudes towards Chinese apparel among South African consumers. The hypothesis was confirmed (path coefficient $=-0.289, t=-4.005, p<0.001$ ). This result was affirmed by a moderate negative association between the two constructs $(r=-0.220, p<0.001)$. This result suggests that South African consumers have moderate negative ethnocentric feelings towards Chinese apparel. The second hypothesis $\left(\mathrm{H}_{2}\right)$ predicted a negative relationship between EA and attitudes towards Chinese apparel among South African consumers. $\mathrm{H}_{2}$ was supported (path coefficient $=-0.211, t=-3.373, p<0.001)$. This finding was also validated by the existence of moderate negative relationship between the two variables $(r=-0.294, p<0.001)$. This result suggests the resentment of South African consumers towards Chinese apparel.

The third hypothesis $\left(\mathrm{H}_{3}\right)$ postulated that cosmopolitanism positively influences attitudes towards Chinese apparel 
among South African consumers. The hypothesis was confirmed (path coefficient $=0.484, t=5.884, p<0.001$ ). This result was supported by a moderate positive association between the two constructs $(r=0.270, p<0.001)$. This result suggests the willingness of South African consumers to try Chinese apparel. Lastly, the fourth hypothesis (H4) posited a positive relationship between attitudes towards Chinese apparel and CPI. This hypothesis was confirmed (path coefficient $=0.560, t=9.091, p<0.001$ ). The hypothesis was also supported by a positive moderate relationship between the two constructs $(r=0.452, p<0.001)$. This result affirms the potency of favourable attitudes in enhancing CPI.

\section{Ethical considerations}

Respondents participated voluntarily and no incentives were offered.

\section{Discussion}

The study examined the influence of consumer ethnocentrism, EA and cosmopolitanism on South African consumers' attitudes and purchase intention towards Chinese apparel. It indicated that South African consumers harbour negative yet moderate feelings of ethnocentrism towards Chinese apparel. Based on this result, it can be inferred that South African consumers who participated in the study do not hold extreme feelings of ethnocentrism. An inspection of consumer responses showed that two statements on the consumer ethnocentrism scale: 'buy South African-made products, keep South Africa working' and 'It is not right to purchase foreign products because it puts South Africans out of jobs' attained the highest, strongly agree (5) rating. This score seems to suggest that preserving employment is upmost in South African consumers when making a purchase decision of Chinese apparel. This result resonates with previous research by Shimp and Sharma (1987) that revealed highly ethnocentric consumers perceive that the purchase of foreign products retards economy growth and triggers unemployment. This concern could be one reason for feelings of ethnocentrism in South Africa as unemployment is estimated to be $25.5 \%$ (Statistics SA 2015).

However, it is important to note that the moderate levels of ethnocentrism could be attributed to diverse cultural orientation that results in multiple consumption cultures (Pentz et al. 2014). According to Phau and Chan (2003), collectivistic cultures depict more ethnocentrism tendencies than diverse ethnic groups, which is the case in South Africa. The key question that remains unanswered, however, is whether this finding constitutes a growing trend of South African consumers who value safeguarding employment by buying home-made products.

In terms of consumer animosity, the results confirmed that South African consumers' animosity is negatively associated with attitudes towards Chinese apparel. The study also confirmed the existence of a strong positive relationship between consumer ethnocentrism and animosity $(r=0.428$; $p<0.01)$. The perception that Chinese firms are dumping low-quality products in developing countries (Gao et al. 2013) could explain the high levels of animosity directed to Chinese apparel in South Africa. For instance, more than $60 \%$ of respondents agreed with the statement, 'China has too much influence on the South African economy' in the consumer animosity scale, indicating high levels of consumer animosity towards Chinese apparel. However, the relatively modest correlation between consumer animosity and attitudes towards Chinese apparel $(r=-0.294, p<0.01)$. This result seems to imply that not all consumers resent Chinese products. This may be attributed to lower prices of Chinese products that make them more affordable to people with low disposable incomes. For instance, a study conducted by Nes et al. (2012) showed that the level of animosity towards foreign products is potentially diluted by the unavailability of domestic alternatives and high quality of foreign products.

The results also indicated that cosmopolitanism was positively associated with attitudes towards Chinese apparel, consistent with previous studies (Parts \& Vida 2011). Such a positive association $(r=0.270, p<0.01)$ implies the willingness of South African consumers to try Chinese apparel. As global markets continue to converge, Strizhakova et al. (2012) observed the emergence of a cohort of young global-oriented consumers who are not swayed by nationalist sentiments when evaluating foreign-made products. This seems to be the case in this study as approximately $87.5 \%$ of the respondents are young consumers below the age of 40 years, implying that they are adopting a global posture in buying behaviour. This view gains empirical supports from a study conducted by Bahram, Mojtabaand Kazem (2011), which showed that young consumers manifest variety-seeking consumption behaviour and are less influenced by ethnocentric considerations when making purchase decisions. According to Zhang and Khare (2009), consumers with high levels of cosmopolitanism are driven by the quest for a global consumption identity, resulting in a positive attitudinal response towards foreignmade products.

Lastly, the study showed that the respondents' attitudes had a positive significant relationship with CPI towards Chinese apparel. This finding supports the TRA's proposition that attitude is a precursor for behaviour intention (Fishbein \& Ajzen 1975). This result suggests that levels of consumer ethnocentrism and animosity in this study are not strong enough to weaken purchase intentions towards Chinese apparel. The most plausible reason could be that the emotive and normative elements of attitudes are outweighed by the cognitive component, which is based on rational assessments centred on affordable Chinese apparel.

\section{Implications of marketing practice and policy formulation}

The findings of this study have important implications to Chinese and South African marketing managers. The reported moderate levels of consumer ethnocentrism and animosity could assist South African marketers to engage in marketing 
communication campaigns that promote South African products. Marketing messages that emphasise the importance of buying South African products to support the economy are more likely to appeal to segments with high levels of ethnocentrism. It is important for Chinese apparel marketers to identity market segments with high levels of hostility towards their products and manage country of origin perceptions. This can be done by emphasising distinctive features of Chinese apparel such as affordability and status that resonate with consumers in developing economies such as South Africa. The Chinese marketers may also use the levels of consumer ethnocentrism and animosity to predict CPIs. Both South African and Chinese marketers could also use consumer ethnocentrism, animosity and cosmopolitanism as additional variables in market segmentation, targeting and positioning as they significantly influence attitudes towards foreign products. On a broader perspective, Chinese marketers may need to develop strategic alliances with South African apparel companies as a way of mitigating ethnocentrisminduced apathy to Chinese apparel. This view is supported by a study by Fong et al. (2014) that showed foreign-entry modes such as joint ventures and strategic alliances have the potential of diluting high levels of EA and consumer ethnocentrism. At a macro-level, the Chinese government needs to engage in concerted efforts of national branding, particularly in changing consumers' enduring perceptions that Chinese products are counterfeit.

\section{Limitations and avenues for further research}

This study has inherent limitations, which offer directions for further research. The study was based on one product category (apparel); hence, the findings may not be generalised to other product categories. Thus, future studies may seek to substantiate the results with more product categories such as electronics or furniture. In addition, other factors likely to influence attitudes towards foreign products such as country of origin, demographic variables and acculturation were not included in the research model. Thus, future studies may seek to develop an integrated model that comprehensively assesses attitudes of South African consumers towards Chinese apparel. Future studies may also extend the geographical location of the study in order to have a holistic South African insight of attitudes and purchase intention towards Chinese products. Future research endeavours could also test whether cosmopolitanism reported among South African consumers moderates the relationship between consumer ethnocentrism and EA. Notwithstanding these limitations, the findings of the study contribute to the understanding of consumer attitudes and purchase intention towards Chinese apparel in South Africa.

\section{Conclusion}

This study has contributed to the understanding of South African consumers' attitudes and purchase intention towards Chinese apparel. It found that consumer ethnocentrism and
EA negatively influence attitudes towards Chinese apparel among consumers in South Africa. The study, however, showed a positive association between cosmopolitanism and attitudes towards Chinese apparel. Based on its findings, consumer ethnocentrism, EA and cosmopolitanism are central in international market segmentation, market potential analysis and formulation of positioning strategies in global markets. However, conventional segmentation variables such as demographics and psychographics still play a crucial role. It would be useful for Chinese marketers to engage in marketing research efforts to understand the underlying causes of consumer animosity towards Chinese apparel.

\section{Acknowledgements}

The authors thank Vaal University of Technology for funding this study.

\section{Competing interests}

The authors declare that they have no financial or personal relationships which may have inappropriately influenced them in writing this article.

\section{Authors' contributions}

A.M. conceptualised the study, R.M.S. conducted literature review and M.D. conducted data analysis.

\section{References}

Ahmed, Z., Anang, R., Othman, N. \& Sambasivan, M., 2013, 'To purchase or not to purchase US products: Role of religiosity, animosity and Ethno-centrism among Malaysian consumers', Journal of Services Marketing 27(7), 551-563. https://doi. org/10.1108/JSM-01-2012-0023

Ajzen, I., 2001, 'Nature and operation of attitudes', Annual Review of Psychology 52, 27-58. https://doi.org/10.1146/annurev.psych.52.1.27

Akdogan, M.S., Ozgener, S., Kaplan, M. \& Coskun, A., 2012, 'The effects of consumer ethnocentrism and consumer animosity on the re-purchase intent: The moderating role of consumer loyalty', Emerging Markets Journal 1, 1-12. https:// doi.org/10.5195/EMAJ.2012.15

Alden, C. \& Wu, Y.-S., 2014, South and China: The making of a partnership, Occasional Paper 199, Southern African Institute of International Affairs, Johannesburg.

Amine, L.S., 2008, 'Country-of-origin, animosity and consumer response: Marketing implications of anti-Americanism and Francophobia', International Business Review 17, 402-422. https://doi.org/10.1016/j.ibusrev.2008.02.013

Anderson, J.C. \& Gerbing, D.W., 1988, 'Structural equation modeling in practice: A review and recommended two-step approach', Psychological Bulletin 103, 411-423. https://doi.org/10.1037/0033-2909.103.3.411

Bagozzi, I.R.P. \& Yi, Y., 2012, 'Specification, evaluation and interpretation of structural equation models', Journal of the Academy of Marketing Science 40, 8-34. https:// doi.org/10.1007/s11747-011-0278-x

Bahaee, M. \& Pisani, M.J., 2009, 'Iranian consumer animosity and US products: A witch's brew or elixir?', International Business Review 18(2), 199-210. https://doi. org $/ 10.1016 / \mathrm{j}$.ibusrev.2009.02.002

Bahram, R., Mojtaba, B. \& Kazem, Z., 2011, 'Ethnocentrism among Iranian consumer with different consumption habits', International Journal of Marketing Studies $3(3), 30-41$.

Bandyopadhyay, S., 2014, 'Country-of-origin perceptions, consumer ethnocentrism and product evaluations in the Indian market', International Journal of Business and Social Science 5(9), 21-30.

Besada, H., Tok, E. \& Winters, K., 2013, 'South Africa in the BRICS opportunities, challenges and prospects', Africa Insight 42(4), 1-15.

Bevan-Dye, A., Garnett, A. \& De-Klerk, N., 2012, 'Materialism, status consumption and consumer ethnocentrism amongst black generation Y Students in South Africa', African Journal of Business Management 6(16), 5578-5586. https://doi.org/ 10.5897/AJBM11.1803 
Bian, Q. \& Forsythe, S., 2012, 'Purchase intention for luxury brands: A cross cultural comparison', Journal of Business Research 65(10), 1443-1451. https://doi. org/10.1016/j.jbusres.2011.10.010

Cannon, H.M. \& Yaprak, A., 2002, 'Will the real-world citizen please stand up! The many faces of cosmopolitan consumer behaviour', Journal of International Marketing 10(4), 30-52. https://doi.org/10.1509/jimk.10.4.30.19550

Cleveland, M., Erdogan, S., Arikan, G. \& Poyraz, T., 2011, 'Cosmopolitanism, individuallevel values and cultural-level values: A cross-cultural study', Journal of Busines Research 64, 934-943. https://doi.org/10.1016/j.jbusres.2010.11.015

Cleveland, M., Laroche, M. \& Papadopoulos, N., 2009, 'Cosmopolitanism, consume ethnocentrism and materialism: An eight-country study of antecedents and outcomes', Journal of International Marketing 17(1), 116-146.

De Nisco, A., Mainolfi, G., Marino, V. \& Napolitano, M.R., 2016, 'Effect of economic animosity on consumer ethnocentrism and product-country images. A binational study on the perception of Germany during the Euro crisis', European Management Journal 34(1), 59-68. https://doi.org/10.1016/j.emj. 2015.09.003

Dimofte, C.V., Johansson, J.K. \& Bagozzi, R.P., 2010, 'Global brands in the United States: How consumer ethnicity mediates global brand effect', Journal of International Marketing 18(3), 81-106. https://doi.org/10.1509/jimk.18.3.81

Dmitrovic, T., Vida, I. \& Reardon, J., 2009, 'Purchase behaviour in favour of domestic products in the West Balkans', International Business Review 18, 523-535. https:// doi.org/10.1016/j.ibusrev.2009.05.003

Edwards, L. \& Jenkins, R., 2013, The impact of Chinese import penetration on the South African manufacturing sector, A Southern Africa Labour and development Research Unit Working Paper Number 102, SALDRU, University of Cape Town, Cape Town.

Field, A., 2009, Discovering statistics using SPSS, Sage, London

Fishbein, M. \& Ajzen, I., 1975, Belief, attitude, intention and behaviour: An introduction to theory and research, Addison-Wesley, Reading.

Fong, C., Lee, C. \& Du, Y., 2014, 'Consumer animosity, country of origin and foreignentry mode choice: A cross country mode', Journal of International Marketing 22(1), 62-76. https://doi.org/10.1509/jim.13.0079

Fornell, C. \& Larcker, D.G., 1981, 'Evaluating structural equation models with unobservable variables and measurement error', Journal of Marketing Research 18, 39-50. https://doi.org/10.2307/3151312

Gao, R., Andras, T.L. \& Huang, Y., 2013, 'Investigating the interrelatedness among consumer animosity, cosmopolitanism and consumer ethnocentrism and the predictive power of animosity: A two-country study', American Marketing Association 1, 351-352.

Gupta, S.L., 2011, Marketing research, Excel Books, New Delhi.

Hair, J., Black, W., Babin, J. \& Anderson, R., 2009, Multivariate data analysis, 7th edn., Prentice Hall, New Jersey.

Hoffmann, S., Mai, R. \& Smirnova, M., 2010, 'Conceptualizing consumer animosity', American Marketing Association 1, 250-251.

Jimenez, N.H. \& Martn, S.S., 2010, 'The role of country-of-origin, ethnocentrism and animosity in promoting consumer trust. The moderating role of familiarity', International Business Review 19, 34-45. https://doi.org/10.1016/j.ibusrev. 2009.10.001

Jin, B. \& Kang, J., 2011, 'Purchase intention of Chinese consumers toward a US appare brand: A test of a composite behavior intention model', Journal of Consumer Marketing 28(3), 187-199. https://doi.org/10.1108/07363761111127617

Keegan, W.J. \& Green, M.C., 2008, Global marketing, 5th edn., Pearson Prentice Hall, New Jersey.

Kim, K. \& Cheong, Y., 2011, 'The effects of athlete-endorsed advertising: The moderating role of the athlete-audience ethnicity match', Journal of Spor Management 25, 143-155. https://doi.org/10.1123/jsm.25.2.143

Klein, J., Ettenson, R. \& Morris, M.D., 1998, 'The animosity model of foreign product purchase: An empirical test in the People's Republic of China', Journal of Marketing 62(1), 89-100. https://doi.org/10.2307/1251805

Kurasawa, F.A., 2004, 'Cosmopolitanism from below: Alternative globalization and the creation of solidarity without bounds', European Journal of Social Science 45(2), 233-255. https://doi.org/10.1017/S0003975604001444

Lamprecht, M., 2014, SA is settling for crumbs from China, City Press. Johannesburg.

Lew, S. \& Sulaiman, Z., 2014, 'Consumer purchase intention toward products made in Malaysia vs. made in China: A conceptual paper', Social and Behavioral Sciences 130, 37-45. https://doi.org/10.1016/j.sbspro.2014.04.005

Liu, F., Murphy, J., Li, J. \& Liu, X., 2006, 'English and Chinese? The role of consumer ethnocentrism and country of origin in Chinese attitudes towards signs', Australasian Marketing Journal 14(2), 5-16. https://doi.org/10.1016/ S1441-3582(06)70057-X

Malhotra, N.K., 2009, Marketing research: An applied orientation, 6th edn., Prentice Hall, Englewood Cliffs, NJ.

Malhotra, N.K. \& McCort, J.D., 2001, 'A cross-cultural comparison of behavioral intention models: Theoretical consideration and an empirical investigation' International Marketing Review 18(3), 235-269. https://doi.org/10.1108/02651 330110396505

Merton, R.K., 1957, Patterns of influence: Local and cosmopolitan influential, Social theory and social structure, The Free Press, New York.
Morris, M. \& Einhorn, G., 2008, 'Globalisation, welfare and competitiveness: The impacts of Chinese imports on the South African clothing and textile industry', Competition and Change 12(4), 355-376. https://doi.org/10.1179/102452908X 357301

Nes, E.B., Yelkur, R. \& Silkoset, R., 2012, 'Exploring the animosity domain and the role of effect in a cross-national context', International Business Review 21, 751-765. https://doi.org/10.1016/j.ibusrev.2011.08.005

Nijssen, E.J. \& Douglas, S.P., 2004, 'Examining the animosity model in a country with a high level of foreign trade', International Journal of Research in Marketing 21, 23-38. https://doi.org/10.1016/j.ijresmar.2003.05.001

Obiorah, N., 2007, 'Who's afraid of China in Africa? Towards an African civil society perspective on China-Africa relations', in F. Manji \& S. Marks (eds.), African perspectives on China in Africa, pp. 35-55, Fahamu, Oxford.

Pallant, J., 2011, SPSS survival manual: A step by step guide to data analysis using SPSS, 5th edn., McGraw-Hill Education, Berkshire.

Parker, R.S., Haytko, A.L. \& Hermans, C.M., 2011, 'Ethnocentrism and its effect on the Chinese consumer: A threat to foreign goods?', Journal of Global Marketing 24, 4-17. https://doi.org/10.1080/08911762.2011.545716

Parts, O. \& Vida, I., 2011, 'The effects of consumer cosmopolitanism on purchase behaviour of foreign versus domestic products', Managing Transitions 9(4), 355-370.

Pentz, C.D., Terblanche, N.S. \& Boshoff, C., 2014, 'Demographics and consumer ethnocentrism in a developing country context: A South African study', South African Journal of Economics and Management Sciences 17(4), 412-426. https:// African Journal of Economics and $M$
doi.org/10.4102/sajems.v17i4.570

Phau, I. \& Chan, K.W., 2003, 'Targeting East Asian markets: A comparative study on national identity', Journal of Targeting, Measurement and Analysis for Marketing 12(2), 157-172. https://doi.org/10.1057/palgrave.jt.5740105

Plassmann, H., Ramsøy, T.Z. \& Milosavljevic, M., 2012, 'Branding the brain: A critical review and outlook', Journal of Consumer Psychology 22(1), 18-36. https://doi. org/10.1016/j.jcps.2011.11.010

Polit, D.F., Beck, C.T. \& Hungler, B.P., 2001, Essentials of nursing research: Methods, appraisal and utilization, 5th edn., Lippincott, Philadelphia, PA.

Purwanto, E., 2014, 'The effect of consumer ethnocentrism on perceived domestic product quality and purchase intentions among young consumers in Jakarta, Indonesia', International Journal of Asian Social Science 4(9), 1003-1012.

Rebol, M., 2010, 'Public perceptions and reactions: Gauging African views of China in Africa', African Journal of Agricultural Research 5(25), 3524-3535.

Riefler, P., 2012, 'Why consumers do (not) like global brands: The role of globalization attitude, GCO and global brand origin', International Journal of Research in Marketing 29, 25-34. https://doi.org/10.1016/j.ijresmar.2011.11.001

Riefler, P. \& Diamantopoulos, A., 2007, 'Consumer animosity: A literature review and a reconsideration of its measurement', International Marketing Review 24(1), 87-119. https://doi.org/10.1108/02651330710727204

Riefler, P. \& Diamantopoulos, A., 2009, 'Consumer cosmopolitanism: Review and application of the CYMYC Scale', Journal Business Research 62(4), 407-419. https://doi.org/10.1016/j.jbusres.2008.01.041

Riefler, P., Diamantopoulos, A. \& Siguaw, J.A., 2012, 'Cosmopolitan consumers as a target group for segmentation', Journal of International Business Studies 43, 285-305. https://doi.org/10.1057/jibs.2011.51

Roth, K.P. \& Diamantopoulos, A., 2009, 'Advancing the country image construct', Journal of Business Research 62(7), 726-740. https://doi.org/10.1016/j.jbusres. 2008.05.014

Schnettler, B., Miranda, H., Lobos, G., Sepulveda, J. \& Denegri, M., 2011, 'A study of the relationship between degree of ethnocentrism and typologies of food purchase in supermarkets in Central Southern Chile', Appetite 56, 704-712. https://doi.org/10.1016/j.appet.2011.02.007

Schroeder, J.E., 2009, 'The cultural codes of branding', Marketing Theory 9(1), 123-126. https://doi.org/10.1177/1470593108100067

Shimp, T.A. \& Sharma, S., 1987, 'Consumer ethnocentrism: Construction and validation of the CETSCALE', Journal of Marketing Research 24(3), 280-289. https://doi.org/10.2307/3151638

Skrbis, Z., Kendall, G. \& Woodward, I., 2004, 'Locating cosmopolitanism: Between humanist ideal and grounded social category', Theory, Culture and Society 21(6), 115-136. https://doi.org/10.1177/0263276404047418

Smith, M. \& Qianpin, L., 2010, 'The role of occupation in an integrated boycott model: A cross-regional study in China', Journal of Global Marketing 23(2), 109-126. https://doi.org/10.1080/08911761003673421

Statistics SA, 2015, Statistical release P0211: Quarterly labour force survey, viewed 20 August 2015, from www.statssa.gov.za/publications/P0211/P02114thQuarter 2014.pdf.

Steenkamp, J. \& De Jong, M., 2010, 'A global investigation into the constellation of consumer attitudes toward global and local products', Journal of Marketing 74 18-40. https://doi.org/10.1509/jmkg.74.6.18

Strizhakova, Y., Coulter, R.A. \& Price, L.L., 2012, 'The young adult cohort in emerging markets: Assessing their global cultural identity in a global marketplace International Journal of Research in Marketing 29, 43-54. https://doi.org/ 10.1016/j.ijresmar.2011.08.002

Sumner, W.G., 1906, Folkways: The sociological importance of usages, manners, customs, mores, and morals, Ginn and Company, New York. 
Wang, T., Zhou, L., Mou, Y. \& Zhao, J., 2014, 'Study of country-of-origin image from legitimacy theory perspective: Evidence from the USA and India', Industria legitimacy theory perspective: Evidence from the USA and India', Industria Marketing Management 43, 769-776. https://doi.org/10.1016/j.indmarman.
2014.04.003

Wang, W., He, H. \& Li, Y., 2013, 'Animosity and willingness to buy foreign products: Moderating factors in decision-making of Chinese consumers', Asia Pacific Business Review 19(1), 32-52. https://doi.org/10.1080/13602381.2011.640133

Wasserman, H., 2012, 'China in South Africa. The media's response to a developing relationship', Chinese Journal of Communications 5(3), 336-354. https://doi.org/ $10.1080 / 17544750.2012 .701428$
Yegenoglu, M., 2005, 'Cosmopolitanism and nationalism in a globalised world', Ethical Racial Studies 28(1), 103-131. https://doi.org/10.1080/0141987042000280030

Zeleza, P.T., 2008, 'Dancing with the dragon, Africa's courtship with China', The Global South 2(2), 171-187. https://doi.org/10.2979/GSO.2008.2.2.171

Zhang, Y. \& Khare, A., 2009, 'The impact of accessible identities on the evaluation of global versus local products', The Journal of Consumer Research 36(3), 524-537. https://doi.org/10.1086/598794

Zikmund, G.W. \& Babin, J.B., 2010, Essentials of marketing research, 4th edn., SouthWestern Cengage Learning, Mason. 